\title{
Reading Picturebooks as Literature: Four-to-Six-Year-Old Children and the Development of Literary Competence
}

\author{
Coosje van der Pol
}

Published online: 15 February 2012

(C) The Author(s) 2012. This article is published with open access at Springerlink.com

\begin{abstract}
This article explores what it means to be a competent reader of picture storybooks by examining the abilities of some 4-6-year-olds, who were read stories aloud in class. Jonathan Culler's concept of "literary competence" was used to tease out the children's implicit knowledge of the structures and conventions that enable them to read a work of fiction as literature. From a more practical point of view, Lawrence Sipe's class-based work, discussing picture storybooks with first and second grade children, provided some useful guidelines. This current study draws on an educational design experiment involving "literary conversation guides," which help probe children's understanding of such story features as character and irony.
\end{abstract}

Keywords Literary competence · Pre-school children · Picturebooks ·

Educational design experiment

\section{Introduction}

In the lower grades of Dutch primary schools picture storybooks are read aloud to children almost every day. An important objective of reading aloud is to promote literacy development and vocabulary learning in particular (see, among others,

Coosje van der Pol has a Master's in Culture Studies from Tilburg University and a PhD in Culture Studies from the same university. She is currently working as a lecturer on the "Children's Literature" Master's course at Tilburg University and also lectures on "Sociology of the Arts" at the same university. She writes picturebook reviews and articles on children's responses to picturebooks for various journals (e.g. De Leeswelp, Leesgoed) and also gives guest lectures at teacher training colleges in the Netherlands and Flanders.

C. van der Pol (ه)

Department of Language and Culture Studies, Faculty of Humanities, Tilburg University, Dante Building, Room 222, P.O. Box 90153, 5000 LE Tilburg, The Netherlands

e-mail: j.a.vdrpol@uvt.nl 
Bus et al., 1995). Also picturebook read-alouds serve as "stepping-stones" for various educational and pedagogical activities, for instance understanding traffic signs or learning how to fly a kite (Van der Pol, 2010). These kinds of reading take an instrumental approach to picture storybooks and are usually less concerned with literary skills or "literary competence." One might wonder why the most obvious thing that can be done with children's literature, that is to read it as literature, does not receive more attention in primary education.

Although literary competence has become more of an issue in primary education over the last few years there is no consensus on what the concept actually involves. Also there is very little practical knowledge on the use of the concept with young children (Van der Pol, 2010). When it is mentioned in professional publications or in policy documents literary competence often appears to be used as a catch-all term (including activities such as searching for books in the library) or is described in a very general sense (for instance, as "the ability to read literary texts").

In the learning objectives of the first two years of primary education (in the Netherlands called groups 1 and 2, for pupils aged four to six) literary competence is not mentioned as such. Although it could be said to be involved in the intermediate objectives of Dutch language-learning (Verhoeven et al., 1999), more specifically in the topics of "book orientation" (concerned with issues like title, writer, illustrator, text, pictures and pages) and "narrative understanding" (concerned with issues like characters, episodes and setting). Teachers, however, often find it difficult to address the abstract issues involved in "narrative understanding" with young children. It is therefore relevant to find out how picturebook read-alouds can stimulate the development of narrative understanding or literary competence, understood as knowledge of the ways in which stories are structured and create meaning. For this reason, a $\mathrm{PhD}$ research project ${ }^{1}$ was carried out that investigates what signs of literary competence 4-6-year-olds already display and how that competence can be expanded by reading picture storybooks and talking about them in a literatureorientated way.

\section{Literary Understanding and Literary Competence}

In his award-winning study "The Construction of Literary Understanding by First and Second Graders in Oral Response to Picture Storybook Read-Alouds," Lawrence Sipe (2000) focussed on the social construction of literary understanding indicated by children's verbal responses to picture storybooks. Sipe looked at the literary understanding of 6- and 7-year-olds through multiple theoretical lenses, such as semiotics, visual aesthetic theory, schema and cognitive flexibility theory, and a range of theories from contemporary literary criticism. The concept of

\footnotetext{
1 The PhD project was part of a larger project called "Picture books and concept development" (PiCo), a multi-centre project in the Netherlands involving, in addition to "literary competence," the concepts of social and emotional development, and mathematics. Each concept was developed empirically using educational design experiments (Cobb et al., 2003) and subsequently tested in a randomised controlled trial. The literary competence project has been published in a $\mathrm{PhD}$ thesis in Dutch with a summary in English (Van der Pol, 2010).
} 
"literary competence" was also included in Sipe's theoretical lenses. He referred to it rather briefly by saying that:

Children and (their teacher) together construct their own implicit definition of literary competence (Culler, 1975) within the constraints and opportunities of their interpretative community (Fish, 1980). (Sipe, 2000, p. 260)

Culler's concept of literary competence, which is rooted in structuralism, Sipe considered a "traditional perspective" (Sipe, 2000, p. 255) on literary understanding. From the structuralist point of view, Sipe continued:

stories may be viewed as stimulating the perception of formal patterns (e.g., the home-away-home pattern represented in Where the Wild Things Are [Sendak, 1963], or binary opposites like good/evil or beauty/ugliness), which are useful for understanding how the story works. (Sipe, 2000, p. 255)

Literary understanding, Sipe argued, may, however, be conceptualised in a broader, richer, and more textured way by applying concepts from a range of theories that are integrated by the idea of literary understanding as a social construction. In his study Sipe modelled children's responses to picture storybooks into five conceptual categories of literary understanding: the analytical, the intertextual, the personal, the transparent and the performative, each category being characterised by different stances, actions, and functions. Analytical responses, in which children deal with a picturebook as an object or cultural product, represent 73 per cent of all the children's spontaneous responses. When responding analytically, children stay with the story and make comments that reflect an analytical stance, for instance about the book as a cultural artefact (produced by an author, illustrator, publisher and printer), about the language in which the story is told, the illustrations, narrative interpretations and the relation between fiction and reality. According to Sipe these five categories constitute the enactments of three basic literary impulses: the hermeneutic impulse (the drive to understand the story and interpret it), the personalising impulse (to link the story to the self and the personal experience), and the aesthetic impulse (either responding receptively to the story as a lived-through experience or using the story as the platform for one's own creative expression). Sipe derives from this the idea that "Literary understanding is the dynamic process whereby these three impulses are activated and synergistically interact with each other" (Sipe, 2000, p. 271).

In his study Sipe raised some interesting ideas about Culler's concept of literary competence. But since Sipe was particularly interested in a multifaceted conception of literary understanding, he did not explore the idea of literary competence in great detail. We therefore are not sure what the suggested implicit definition of literary competence by children and their teacher involves; and whether it can be made explicit when we wish to describe it. Also it is unclear what constitutes the possible constraints and opportunities of an interpretative community of 4-6-year-olds. And can the opportunities be expanded by offering teachers and children tools for a more conscious literary approach to children's books? When taking a closer look at Culler's concept of literary competence, it proves to have a strong educational potential which so far has not received any in-depth exploration as far as young children are concerned. 


\section{Literary Competence}

Culler (2002/1975) has based his idea of literary competence on an analogy with Noam Chomsky's (1965) concept of linguistic competence. Chomsky argues that to understand a sequence of words as a sentence one must be familiar with the system-or structure - of the language in which the sentence is spoken. People, even at a very young age, have an internalised grammar which Chomsky calls "linguistic competence." Without this competence a sentence (or rather a sequence of sounds) will be meaningless to the listener, literally "nothing but hot air." By analogy, Culler suggests we may think of structure and meaning as properties of literary works. A literary work has meaning only when it is read, or listened to, in a particular way; when it is read "as literature" (Culler, 2002, p. 149). Literature, Culler argues, therefore depends on particular modes of reading. To read a text as literature:

is not to make one's mind a tabula rasa and approach it without preconceptions; one must bring to it an implicit understanding of the operations of literary discourse which tells one what to look for. (ibid, p. 132)

According to Culler the notion of literary competence does not presume, however, that there is just one proper (competent) way to read literature. If in an interpretative community the practices of reading literature are that readers may interpret works in a variety of ways, then that is a fact about literary competence. The only presumption the concept of literary competence entails, Culler argues, is

that there is learning involved, in coming to read literature, as in learning a language - that readers do acquire both sets of categories and procedures for their application, so that there is something-call it "competence"-to be described. (ibid, p. xi)

Literary competence therefore is both a characteristic of readers (an internalised story grammar) and a description of that competence (a descriptive grammar or poetics). Culler's theoretical discourse on literary competence, however, neither deals with young readers, nor does it go into any possible educational implications. For that reason these issues have been addressed in an educational design experiment.

\section{Educational Design Experiment}

Educational design experiments aim at engineering particular forms of learning and systematically studying those forms of learning within a particular context and using particular means (Cobb et al., 2003). During an educational design experiment teachers and researchers work closely together in the classroom. This collaboration allows the development of theories about the children's learning of key concepts within a well defined domain; for example, within literature this might be to appreciate what a "main character" is. Based on patterns in children's reasoning a theory of this type offers insights into the learning process. It also sheds light on the 
means that encourage that learning; in this case the picture storybooks that are read aloud in the classroom using "literary conversation guides."

Literary conversation guides have been designed to trigger children's thinking about how stories work. This is done by looking at some of the conventions picturebooks employ, for instance showing a picture taken from the story on the front cover. A literary conversation guide also addresses how a particular story is structured and how that structure produces effects such as suspense. There is, for instance, the issue of the intentional distribution of information between reader and character(s) whereby one party is better informed about what will happen in the story than the other. This structural device may lead to suspense or (when the reader knows more) to a sense of superiority in the reader who already knows the protagonist's fate. Each conversation guide contains a brief theoretical description (similar to the above) of a literary phenomenon. It also contains questions and points of attention teachers could use to discuss the phenomenon with children when reading the story. In Dear Little Lamb, (Dutch title: Lief lammetje,) (Kempter and Weldin, 2006) for instance, a nameless lamb receives letters from a mysterious friend signed with the name Wolfgang. Immediately after looking at the front cover, which shows a wolf with a typewriter, the reader knows the sender's identity. After the second letter the children were asked: "Does Little Lamb actually know who this friend is?" The children established that the characters had not actually met each other yet and that Little Lamb could not see the book cover. The children concluded from this that Little Lamb therefore did not know that Wolfgang is a wolf. They also realised the effect of this: "It is scary because the little lamb has not seen the wolf yet but we have!" a girl commented.

The literary conversation guides were tested and optimised in two classrooms of the same primary school. As in Sipe's (2000) study, the teachers were encouraged to use an open, conversational approach and to try to avoid direct questioning. Each reading-aloud session was videotaped and transcribed. The analyses of children's comments, questions and reasoning offer information on what constitutes the literary competence (as far as the selected topics are concerned) of the participating 4-6-year-olds. In addition to this the observation of classroom interactions provided information about the constraints and opportunities for the children's interpretative community.

\section{Story Characters}

The exploration of "story characters" provides a good starting point when reading picturebooks as literature because characters are relatively accessible to young readers. Readers tend to identify with characters more than with any other story element (e.g. Applebee, 1978) and story characters can invite readers to become involved in the story. Therefore topics related to characters that are both relevant to the development of literary competence and of interest to young children were identified first. Subsequently picturebooks containing interesting literary conventions or techniques related to story characters were selected and read aloud to children by their own teacher using the literary conversation guides. 
Reflection on story characters may start from the idea that in a story one or more figures participate. Also relevant is the notion that story characters are not "real" but entirely depend on literary conventions and cultural codes. Furthermore, literary competent readers can distinguish the main character(s) from the additional characters. By doing so a reader decides to whom he or she should pay most attention and places others in relation to that character, which is an important structuring activity (Culler, 2002).

When asked who participated in a story that had just been read to them, children usually managed to sum up all or most of the characters. Although this may seem like a mere memory-test, the question also encourages children to think of the concept of "character." Interestingly enough, when summing up story characters some children also included non-characters, like the rocks or clouds they had seen in the pictures. This led to classroom discussions about what or who can be story characters and what/who cannot. During these conversations children established that some stories feature inanimate objects as story characters (e.g. the house in Virginia Lee Burton's The Little House, 1978/1942) while in other stories housesand also things like rocks and clouds-are just part of the setting. Such conversations made the children more aware of the literary conventions of character construction.

Obviously, when discussing issues concerning story structure and conventions, this should be done in a vocabulary that is accessible to children. "Who takes part in the story?" or "Who plays a part in the story?" proved to be productive formulations. It is also useful of course to listen to the children's own usage, or in Chomsky's (1965) terms "performance," when discussing literary issues. A 4-yearold boy for instance, described a story character as someone who "walks around in the book." Sometimes children are familiar with a particular literary concept but do not know the corresponding vocabulary yet. In other instances children may not know the concept either. Both situations can be considered "teachable moments" in which the teacher can introduce the literary concept and possibly also the words that refer to it (Langer, 1991). In this educational design experiment, however, teaching terminology like "story characters" was not an issue and the children stayed with descriptions like "the animals who play (or take part) in the story."

\section{Main Characters}

Having established who participates in the story, most children managed to identify the main character of that story. Children who successfully pointed out the main character and also managed to explain why he or she is the protagonist answered, for example: "His picture is on the front of the book," "His name is (in) the title of the book," "We see him on every page," or "He's the one who has all the strange adventures." Yet other children clearly related the main character to the role of the hero of the story by saying: "He does everything well," or "He saved his life"; one child even said "He is like the hero." Some children identified the main character correctly but could, however, not explain why that character was the most important figure in the story. This suggests that the correct identification of the protagonist may have been done intuitively, in a way that is still pre-reflective. Again, these 
cases present teachable moments in which knowledge of the subject was "constructed" by children and their teacher in classroom discussions.

Also of interest are responses in which children sum up story characters by relating them (implicitly) to the protagonist, for instance by saying "His mother, his grandmother, his brothers and sisters." Strikingly, these children did not include in their answers the character referred to by the possessive pronoun. It therefore seems that they somehow realise that there is a main character to whom all the others are related, but for some reason they do not mention it. What is more, when asked who the most important character in the story was, these children did not know. This underlines the idea that identifying the main character is sometimes done intuitively and that reflection on the issue may lead to confusion, but at the same time it offers an opportunity to learn about literary conventions.

The literary conversation guides contain various clues to help children to identify the main character. A clue is, for example, that in the illustrations the main character is usually depicted as larger than less important characters. Also the protagonist usually has a personal name, while additional characters often only have generic names (e.g. "the people from the village"). In one illustration from We Honestly Can Look After Your Dog (Child, 2005), for example, we see some boys playing football in the background and then they seem to have disappeared from the story completely. A girl described their role as minor figures thus: "Those boys were only there to play some football and went straight back home again."

\section{Informative "Mistakes"}

The "mistakes" children make (in their performance) are a useful source of information if one is trying to discern the pupils' underlying literary competence. Also "mistakes" can offer learning opportunities. When asked who is the most important figure in Cottonwool Colin (Dutch title: Watje Wimpie) (Willis and Ross, 2007) (Figs. 1 and 2) most children correctly identified Colin (a mouse) as the protagonist. But when asked how one can tell that Colin is indeed the most important character, some children answered "Because he is tiny." or "Because his mother took very good care of him." Both these statements are true in this particular story, but these are not literary reasons why Colin is the protagonist. In real life, children may find that parents take good care of their little ones, because they find their children important. Other children said that the mother mouse was the most important story character "Because she is the boss," or "Because my mummy and daddy are also important." Still other children said the mad fox in the story was the main character "Because he has sharp teeth." His dangerous jaws definitely make the fox an important character to watch, but they do not make him the story's protagonist. The fox only plays a supporting role in the story, which may be discussed in terms of "he only appears once," "he has no name," or "he does not do much" and so on.

However different they are, these examples of children identifying what is actually a supporting character as the main character, all demonstrate that there are important differences between how things work in the real world and in stories. The two "systems" require different sets of rules and conventions. Whatever makes a 
Ze pakt Wimpie in.

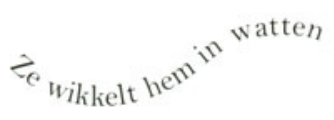

tot alleen zijn voeten nog uitsteken.

Nu is hij Watje Wimpie.

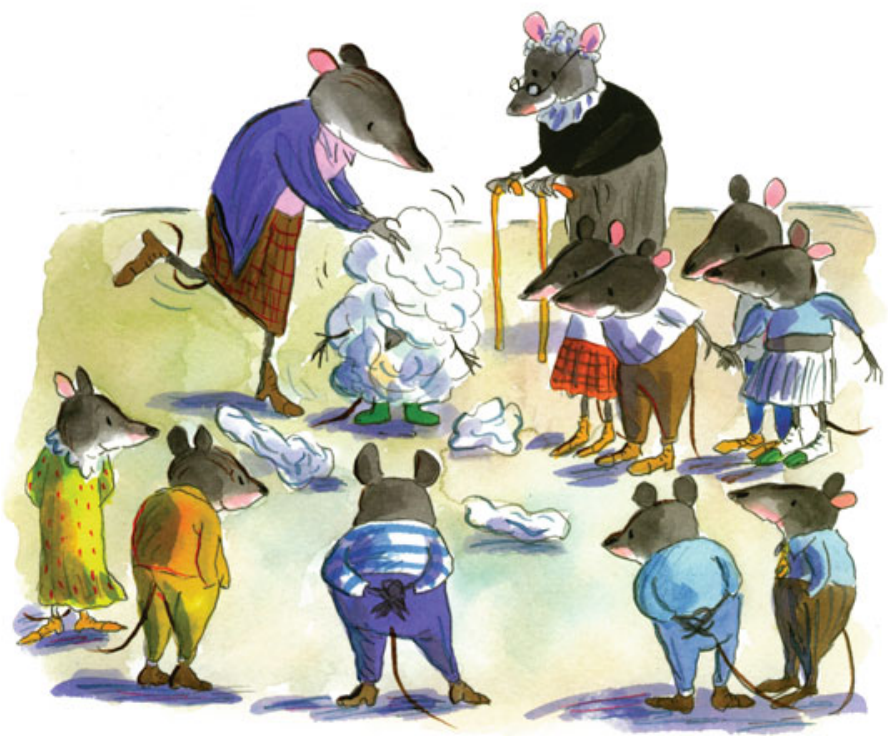

Fig. 1 "His mother, his grandmother, his brothers and sisters." Reprinted with permission from De Vries-Brouwers (the publisher): Jeanne Willis and Tony Ross. Watje Wimpie. Antwerpen: De VriesBrouwers, 2007

person important in real life may not apply to the world of the story and vice versa: something a competent reader of literature is aware of.

\section{(Un)Usual Suspects}

As Sipe (2000, p. 255) also pointed out, binary opposites are an important concept in structuralist literary theory (going back to Ferdinand de Saussure's claim that in linguistics difference is the most important criterion for creating meaning). Many stories feature pairs like villain/hero, cat/mouse or wolf/sheep. These opposites are important structuring principles for storytelling, which is something that children are often aware of, even if only subconsciously. When a villain enters the scene, for instance, they comment that the hero will be there soon, or when the front cover of the book shows a picture of a wolf they predict that there will be a sheep or a goat in the story too. This confirms that 4-6-year-olds already have some mental schemata about how stories work. Once this is established children can move on to story conventions that are a little more demanding; for instance, the convention that a 


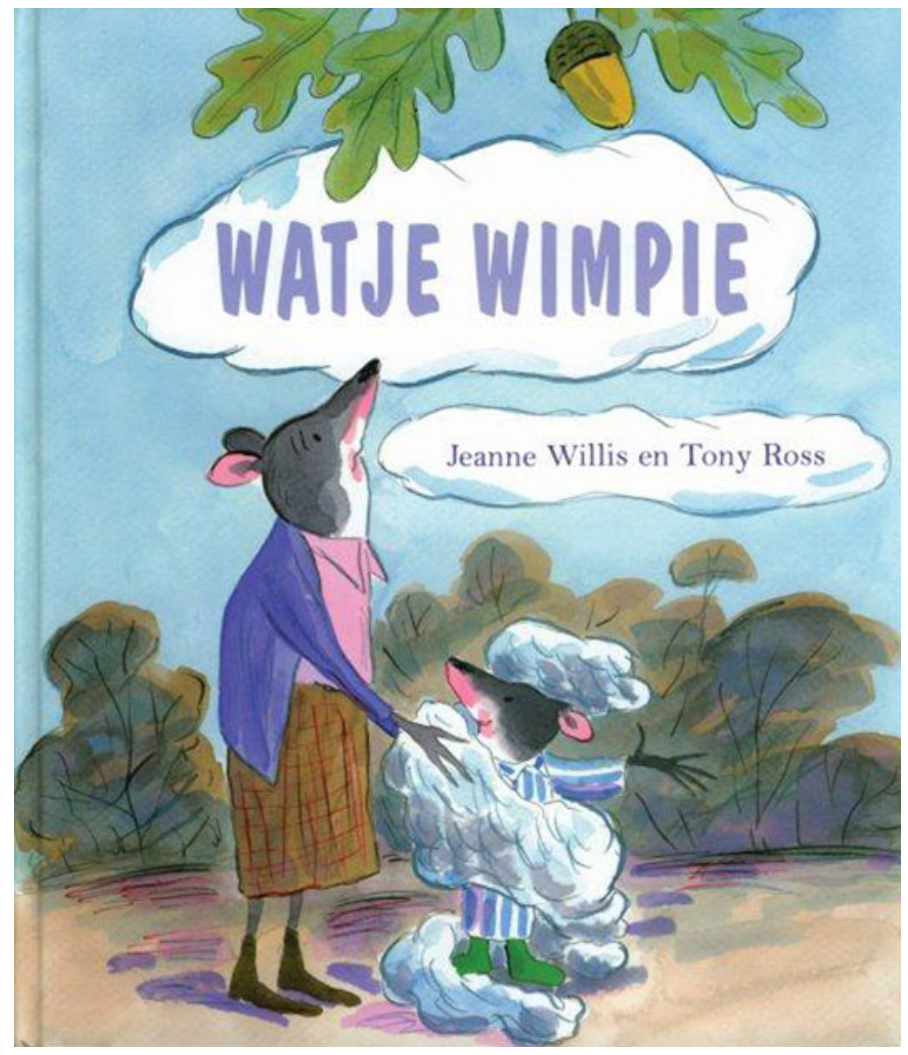

Fig. 2 "His picture is on the front of the book." Reprinted with permission from De Vries-Brouwers (the publisher): Jeanne Willis and Tony Ross. Watje Wimpie. Antwerpen: De Vries-Brouwers, 2007

character has some symbolic meaning. The children who participated in the educational design experiment were remarkably familiar with character conventions such as the brave lion, the sly fox or the trusting little lamb. When one of these characters appeared, children usually knew exactly what to expect. In discussing the typical traits of those characters pupils frequently referred to similar figures in other stories. Their comments often included references to stories from popular culture, ranging from Disney DVDs to stories from the fairytale forest of a well known Dutch theme park, "De Efteling." A lion, for instance, was immediately described as "brave," "strong" and "king of the animals," "like in the Lion King," a 5-yearold boy added.

Once children are familiar with some basic conventions regarding story characters, they will also notice when authors or illustrators play with conventional character traits, for instance by exaggerating or reversing them. This is the case when characters are portrayed ironically: the lion is humble, the fox gets tricked or a wolf and a sheep turn out to be best friends. Children usually realise there is something odd about those characters. A typical reaction-registered when reading Wolves (Gravett, 2005) in which, in an "alternative ending," the wolf does not eat 
the rabbit after all, but has toast with jam instead — was that children found it "funny that a wolf could be a vegetarian."

Irony: "It is not What You Expect"

Using the literary conversation guides the teachers in the educational design experiment helped their pupils to grasp ironic characterisations by using the definition borrowed from Jon Stott (1982): "It is not what you expect." Stott designed for children (in his case 8-year-olds) a simple but effective strategy for interpreting irony in picturebooks: "Something in a story that wasn't what you (or the characters) expected" (ibid, p. 159). Irony in children's stories is usually based on the idea that a reader or a character expects "a" to happen but what actually happens is "not-a" (Kümmerling-Meibauer, 1999). For young children to recognise and interpret this structural technique is quite a challenge, not least because the irony is often implicit. Stott was the first to admit that his definition ("It is not what you expect") might be a huge simplification of the complex phenomenon of irony. But then the definition has the pragmatism required for educational design experiments: it emphasises a major element of irony, unexpected discrepancy, and, as such, alerts young readers to be on the lookout. So when children perceive an ironic character or situation as humorous, their teacher could grasp this "teachable moment" and explain that sometimes it can be funny when someone, like a vegetarian wolf (or something, as is the case in an ironic event), is quite different from how we or another character thought he or she (or it) would be.

\section{Constraints and Opportunities for the Interpretative Community}

In his brief discussion of literary competence, Sipe (2000) refers to the fact that children are both constrained and enabled by the rules of their interpretive community. An important constraint on reading picturebooks as literature appears to be the kind of response that Sipe named the "personalising impulse." Through this impulse children are able to relate the story to their own lives by making "lifeto-text" or "text-to-life" connections (Sipe, 2000, p. 270). This personalising impulse is not entirely trouble-free where the concept of literary competence is concerned. In his theoretical discourse on literary competence, Culler describes the impetuous move from text to life as an "unseemly rush from word to world" (Culler, 2002, p. 151). It is "unseemly" because when reading a text as literature, the reader, Culler argues, is supposed to stay with the literary system for as long as possible and explore it in accordance with the rules and conventions of that system. This resembles the kind of response that Sipe (2000, p. 264) describes, where the "children stayed within the text conceived as a union of visual and verbal sign systems," which is an important characteristic of analytical responses. By rushing from the story world to one's own world, effects that are made possible by the story structure (for example ironic interpretations) may be "overruled" by interpretations that are wholly personal or idiosyncratic. This may lead to premature foreclosure, a situation in which the reader does not "allow the text to differentiate itself from 
ordinary language, to grant maximum scope to the play of formal features and of semantic uncertainties" (Culler, 2002, p. 187).

A paradigmatic case in point occurred when the unmistakably ironic story Jaap Schaap (Vis, 2000) (Fig. 3), about a wolf who turns out to be a sheep's best friend, was read aloud. A highly pragmatic 6-year-old boy "solved" the ironic situation by suggesting that "maybe the wolf was just a dog." He continued by explaining his own experiences with dogs that get along with sheep very well. Here the real world forecloses the story's ambiguity, thereby leaving little room for ironic play. The teacher's enthusiastic response to what he thought a smart solution, however, confirmed that in this particular interpretative community "premature foreclosure" was not considered problematic.

In Jean Piaget's (1972) influential theory of the stages of cognitive development, concrete thinking and egocentrism are important characteristics of 4-6-year-olds. But the practice of relating stories to children's own lives is also actively encouraged in the lower grades of Dutch primary education. As argued earlier, stories are often read to learn about the world or to talk about children's own experiences. Children are explicitly invited to make text-to-life and life-to-text connections. However, by inviting empiricism and pragmatism into the story world straightaway, one cuts short the literary play. The result is that children may not read the story as literature but rather as an "ordinary account" of the world.

The rather impressive number of stories that 4-6-year-olds already seem to be familiar with (Van der Pol, 2010) offers a wealth of opportunity for their interpretative community. The children who participated in the educational design experiment made some interesting intertextual references, with many of their stories

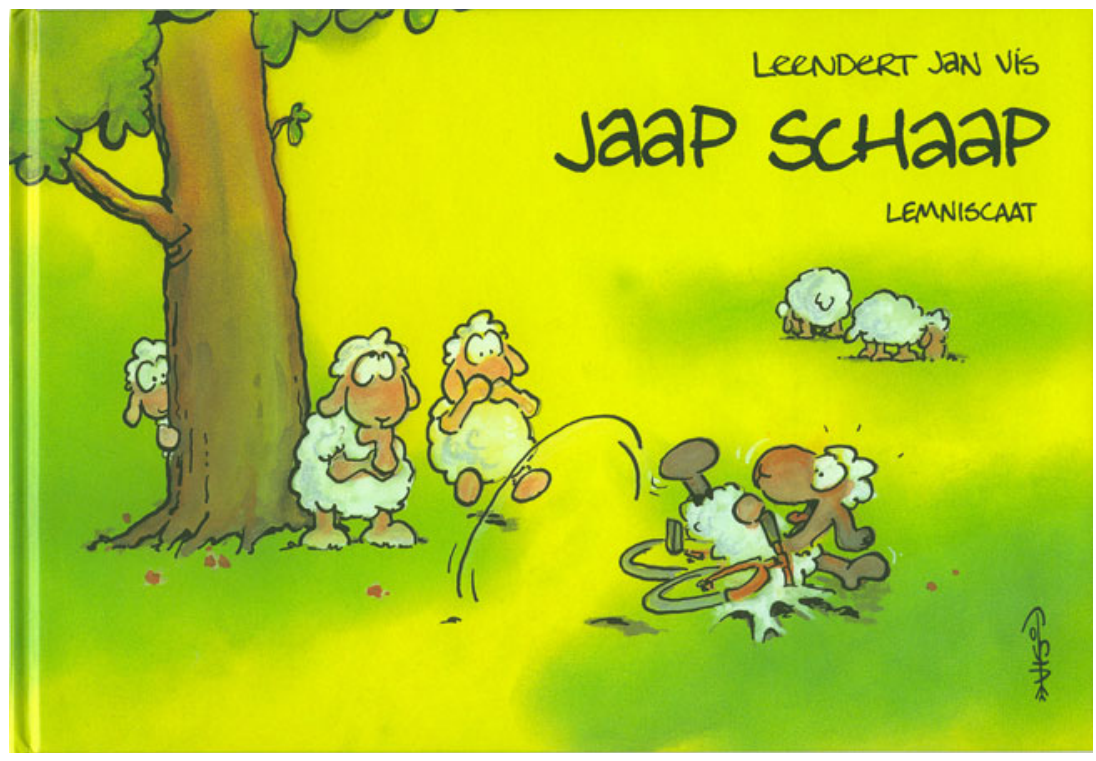

Fig. 3 Reprinted with permission from Lemniscaat (the publisher): Leendert Jan Vis. Jaap Schaap. Rotterdam: Lemniscaat, 2000 
deriving from popular culture, such as animation films, TV shows and theme parks. These findings are consistent with Sipe's (2000, p. 264), where intertextual responses referring to stories from different media made up ten per cent of the total number of responses.

Knowledge of stories from popular culture can promote thinking about the ways stories work in children's literature. When encountering a difficult structural technique like a "flashback" in a picture storybook, it may be understood by referring to this phenomenon in films. In one class, some children explained to their classmates that when in animated cartoons a picture becomes a little hazy and the colours fade to black and white, for instance, it means that the action takes place in the past. Films and animated cartoons, obviously, also employ structural techniques such as "gaps" and binary opposites. Considering film and picture storybooks as "allies" (Mackey, 1993; Meek, 1996) therefore offers numerous opportunities for reading picturebooks as literature.

\section{Conclusions and Discussion}

Culler's notion of literary competence has been used in the above educational design experiments to make explicit the implicit readings of young children, showing what informs their responses, interpretations and solutions to particular textual problems. In short, what competence underlies a certain performance. Of course, competence is itself defined by a particular interpretive community and its norms of what is acceptable; moreover, that normative frame of reference may be adjusted to accommodate new readings if they are communally deemed suitable. However, it will also seek to exclude readings that seem wholly personal or idiosyncratic, for the very reason that to be an experienced reader of literature is "after all, to have gained a sense of what can be done with literary works and thus to have assimilated a system which is largely interpersonal" (Culler, 2002, pp. 148-149).

\section{Children as Structuring Readers}

As Sipe (2000) aptly argued, from the structuralist perspective literary understanding has often been conceptualised in a somewhat restrictive or passive way by focusing on formal text characteristics. But Culler's concept of literary competence-though fundamentally structuralist-is neither restrictive nor passive. Reading picturebooks as literature is not essentially about the teaching of formal text characteristics but aims to describe what a "structuring reader" (Brooks, 1976) does. Structure therefore need not be considered as an objective property of stories: it emerges in structuring processes performed by the reader (albeit on a determinate text). The fact remains, however, that some stories contain more challenging response-inviting structures than others. Also it is true that these "structuring processes" sometimes have to be elicited by thought-provoking questions. By considering children's judgments and intuitions about how stories work we can gain evidence about their structuring activities and underlying literary competence. 
By purposefully eliciting literary response to picturebooks this study took a different approach from the research done by Sipe (2000), who studied children's spontaneous responses to picture storybooks. In Sipe's study the teacher stayed with her normal routine by encouraging children to talk at any point during the story, but maintained an attitude of acceptance rather than direction or evaluation (Sipe, 2000, pp. 261-262). This raises the question of what would happen to children's literary competence if teachers did nothing out of the ordinary and just read the books they were used to in their usual ways. In our research project these questions were answered by means of a randomised controlled trial in which eighteen classrooms participated. Although this experiment is beyond the scope of the present article, the outcome was that the children who were read the twenty-four picturebooks with the literary conversations guides showed a significant increase in literary competence over those in the control groups. This finding confirms the effectiveness of reading picturebooks as literature with the aid of literary conversation guides (Van der Pol, 2010).

\section{The Value of the Linguistic Analogy}

When investigating what constitutes literary competence at the ages of 4-6, the analogy with linguistic competence is illuminating indeed. Although young children have not yet received any formal grammar instruction, they do know how sentences are structured and how that structure enables particular meanings and rules out others. They can understand spoken sentences, even sentences they have never heard before. Children-and most adults too-are usually oblivious to these capacities. As far as young children are concerned, linguistic competence develops through learning by doing and by informal instruction. It flourishes best when a child grows up in a context that is rich in language, both spoken and written. This idea has become well-established in terms of "emergent literacy" (e.g. Sulzby, 1985; Teale and Sulzby, 1986; Bus, 1995). Similarly we may think of "emergent literary competence" by offering children an environment rich in stories that encourage meaningful structuring activities and by having "literary conversations" with them. At a later stage instruction can become more formal and children can learn to reflect on what they have learned tacitly so far.

At the ages of 4-6 most children are particularly interested to find out how things work. We only have to think of the many "why" or "how" questions they ask. Discovering the system(s) behind the events, a structuralist pursuit par excellence, therefore, will not only help make them competent readers of literature, but may also prove to be a source of endless literary discoveries.

Acknowledgment The 'Picture books and concept development' project (2005-2009) was funded by the Programme Council for Educational Research, part of the Netherlands Organisation for Scientific Research (NWO).

Open Access This article is distributed under the terms of the Creative Commons Attribution License which permits any use, distribution, and reproduction in any medium, provided the original author(s) and the source are credited. 


\section{References}

Applebee, Arthur N. (1978). The Child's Concept of Story. Ages Two to Seventeen. Chicago: The University of Chicago Press.

Brooks, Peter. (1976). Competent Readers. Review of: Structuralist Poetics. Structuralism, Linguistics, and the Study of Literature by Jonathan Culler. Diacritics, 6(1), 23-26.

Burton, Virginia L. (1978/1942). The Little House. New York: Houghton Mifflin.

Bus, Adriana G. (1995). Geletterde peuters en kleuters: Theorie en praktijk van ontluikende geletterdheid. Amsterdam: Boom.

Bus, Adriana G., Van Ijzendoorn, Marinus H. and Pellegrini, Anthony D. (1995). Joint Book Reading Makes for Success in Learning to Read: A Meta-Analysis on Intergenerational Transmission of Literacy. Review of Educational Research, 65, 1-21.

Child, Lauren. (2005). We Honestly can Look After Your Dog. London: Penguin Books.

Chomsky, Noam. (1965). Aspects of the Theory of Syntax. Cambridge, MA: The MIT Press.

Cobb, Paul, Confrey, Jere, DiSessa, Andrea, Lehrer, Richard and Schauble, Leona. (2003). Design Experiments in Educational Research. Educational Researcher, 32(1), 9-13.

Culler, Jonathan. (2002/1975). Structuralist Poetics: Structuralism, Linguistics and the Study of Literature. London: Routledge.

Fish, Stanley. (1980). Is There a Text in This Class? The Power of Interpretive Communities. Cambridge MA: Harvard University Press.

Gravemeijer, Koeno and Cobb, Paul. (2006). Design Research from the Learning Design Perspective. In J. van den Akker, K. Gravemeijer, S. McKenney and N. Nieveen (Eds.), Educational Design Research (pp. 151-158). London: Routledge.

Gravett, Emily. (2005). Wolves London: Macmillan.

Kempter, Christa, and Weldin, Frauke. (2006). Dear Little Lamb,. New York: North South Books. (First published in Switzerland under the title Liebes kleines Schaf,. Dutch translation entitled: Lief lammetje,. Rijswijk: De Vier Windstreken.)

Kümmerling-Meibauer, Bettina. (1999). Metalinguistic Awareness and the Child's Developing Concept of Irony: The Relationship Between Pictures and Text in Ironic Picture Books. The Lion and the Unicorn, 23(2), 157-183.

Langer, Judith A. (1991). Envisioning Literature: Literary Understanding and Literature Instruction. Newark/New York: The International Reading Association/Teachers College Press.

Mackey, Margaret. (1993). Picture Books and the Making of Readers: A New Trajectory. NCTE Concept Paper Series No. 7. Urbana, IL: National Council of Teachers of English.

Meek, Margaret. (1996). Information and Book Learning. Stroud: Thimble Press.

Piaget, Jean. (1972). The Child's Conception of the World. Totowa, NJ: Littlefield Adams.

Sipe, Lawrence R. (2000). The Construction of Literary Understanding by First and Second Graders in Oral Response to Picture Storybook Read-Alouds. Reading Research Quarterly, 35(2), 252-275.

Stott, Jon C. (1982). "It's not What You Expect": Teaching Irony to Third Graders (Editorial View). Children's Literature in Education, 13(4), 153-163.

Sulzby, Elisabeth. (1985). Children's Emergent Reading of Favorite Storybooks: A Developmental Study. Reading Research Quarterly, 20(4), 458-481.

Teale, William and Sulzby, Elisabeth (Eds.). (1986). Emergent Literacy: Writing and Reading. Norwood, NJ: Ablex.

Van der Pol, Coosje. (2010). Prentenboeken lezen als literatuur. Een structuralistische benadering van het concept 'literaire competentie' voor kleuters. Amsterdam/Delft: Stichting Lezen/Eburon. (Doctoral thesis, in Dutch with a summary in English).

Verhoeven, Ludo, Aarnoutse, Cor, Blauw, Akke de, Boland, Theo, Vernooy, Kees, and Zandt, Regine van het. (1999). Tussendoelen beginnende geletterdheid. Een leerlijn voor groep 1 tot en met 3. Nijmegen: Expertisecentrum Nederlands.

Vis, Leendert Jan. (2000). Jaap schaap. Rotterdam: Lemniscaat.

Willis, Jeanne and Ross, Tony. (2007). Cottonwool Colin. London: Andersen Press. [Translated in Dutch: Watje Wimpie. Antwerpen: De Vries-Brouwers]. 